\title{
Effects of Supplementing Crude Glycerin in Concentrated Diet and Castration on Carcass Characteristics and Meat Quality of Thai Native $\times$ Anglo Nubian Goats
}

\author{
Anneke $^{1}$, Chaiyawan WATTANACHANT ${ }^{1, *}$ and Saowakon WATTANACHANT ${ }^{2}$ \\ ${ }^{I}$ Department of Animal Science, Faculty of Natural Resources, Prince of Songkla University, \\ Songkhla 90110, Thailand \\ ${ }^{2}$ Department of Food Technology, Faculty of Agro-Industry, Prince of Songkla University, \\ Songkhla 90110, Thailand
}

("Corresponding author's e-mail: chai_tum@yahoo.com)

Received: 13 December 2016, Revised: 8 December 2017, Accepted: 8 January 2018

\begin{abstract}
The effects of feeding concentrate diet containing crude glycerin supplementation and castration on carcass composition and meat quality of Thai Native $\times$ Anglo-Nubian (TN-AN) goats were investigated. Twenty TN-AN goats at the age of 12 months old with $24.75 \pm 1.33 \mathrm{~kg}$ initial live weight were allotted into a $2 \times 2$ factorial arrangement in completely randomized design when factor A was assigned for sexes (intact and castrated male) and factor B was assigned for 2 types of concentrate diet (control diet and diet supplemented with $10 \%$ crude glycerin). Goats were intensively raised in individual pens with ad libitum water and Atratum grass (Paspalum atratum), while $2 \%$ of concentrate diets was provided. After 90 days of feeding, 3 goats from each treatment combination were randomly sampled and sacrificed for further examination. From the study, castrated male goats had significantly higher slaughter and carcass weight, carcass fat percentage and chemical fat percentage than those of the intact males $(\mathrm{P}<0.01)$. In addition, muscle from castrated male goats was more tender and lighter in color as compared with intact male goats $(\mathrm{P}<0.01)$. Goats receiving a diet with extra glycerin had significantly higher weight at slaughter, warm carcass weight, carcass fat, and chemical fat percentages than those on the control diet. Therefore, it could be concluded that feeding goats with a diet of $10 \%$ supplementary glycerin and castration could lead to better slaughter and warm weight, whereas a higher fat content in the carcass and muscle are observed.
\end{abstract}

Keywords: Goat meat, castration, crude glycerin, fat distribution

\section{Introduction}

Goat meat is commonly consumed in many parts of the world, especially in Asia and Africa. Although consumption of goat meat is less compared to pork, poultry and beef [1], this meat has become an alternative healthy red meat due to its low fat and cholesterol contents compared to mutton, pork, beef, and broiler meat [2]. Thus, rearing goats for meat consumption is increasing around the world. To increase growth performance and meat yield, castrating the male goat is an option for fattening whereas concentrate feeding is also necessary [3]. Castration can increase the carcass yield of goats [4], but high fat deposition can be found in the subcutaneous and viscera parts [5]. In terms of concentrate supplementation, it has been confirmed that a concentrate diet is necessary for fattening goats [6]. Thus, a suitable source of energy feedstuffs in various farm size is needed.

In Thailand, since the Ministry of Energy has launched a biofuel policy in the year 2015 to increase biodiesel production from palm oil [7], glycerin, a main by-product from the biodiesel industry is going to increase in the near future. This by-product can be used in the animal feed industry as mentioned by 
http://wjst.wu.ac.th

Thompson and He [8]. Previous studies [9] have reported that crude glycerin can be mixed up to $20 \%$ in total mixed rations, but there is no information of fattening in $50 \%$ Thai Native $(\mathrm{TN}) \times 50 \%$ AngloNubian (AN) goats with fresh Atratum grass and a concentrate diet with $10 \%$ of glycerin. Therefore, the objective of this study was to determine the effects of feeding a concentrate containing glycerin and castration on carcass composition and meat quality of TN $\times$ AN goats.

\section{Materials and methods}

\section{Location, animals and experiment}

This experiment was conducted at the Small Ruminant Research and Development Center (SRRDC), Khlong Hoi Kong Research Station, Faculty of Natural Resources, Prince of Songkla University, Hat Yai, Thailand. Twenty TN $\times$ AN (50:50) male goats at the age of 10 months with $20.00 \pm$ $1.20 \mathrm{~kg}$ initial live weight were selected from the SRRDC herd of approximately 450 goats. The goats were then separated into 2 groups $(n=10$ /group) where group 1 was the intact male group and group 2 was the castrated male group. Goats in the castrated group were castrated using a Burdizzo clamp. Both groups were kept in $3 \times 3 \mathrm{~m}^{2}$ pens under the same environmental conditions for about 2 months.

During this period, goats were fed with ad libitum fresh Atratum grass (Paspalum atratum) and water and 150 grams of concentrate diets per head per day. After adjusting for 2 months, goats with an initial live weight of $24.75 \pm 1.33 \mathrm{~kg}$ were dewormed with IDECTIN ${ }^{@}$ and allotted into a $2 \times 2$ factorial arrangement in a completely randomized design (CRD). Factor A was assigned for 2 types of concentrate diet (control diet and diet added with $10 \%$ glycerin) and factor B was assigned for sexes (intact male and castrated male). During this period, goats were raised intensively for 90 days with ad libitum fresh Atratum and water and $2 \%$ concentrate diets.

The control diet consisted of $12 \%$ Soybean meal, $26 \%$ palm kernel cake, $54.3 \%$ ground corn, 4.7 $\%$ minerals (di-calcium phosphate $1.2 \%$, shell flour $25 \%$ and salt $1.5 \%$ ) and $3 \%$ palm oil (Table 1), while the experimental diet was the control diet with a $10 \%$ glycerin addition. This crude glycerin was purchased from New Biodiesel Ltd. Co., Surat Thani province, Thailand. Feeding of the concentrate diet and roughage were done twice a day in 2 equal portions at $08.30 \mathrm{~h}$ in the morning and in the afternoon at $15.00 \mathrm{~h}$.

\section{Sample preparation}

At the end of the experiment, 3 goats from each treatment combination group were randomly sampled and transferred to the meat lab of SRRDC, Khlong Hoi Kong Research Station, Faculty of Natural Resources to start the pre-slaughter fasting period (for $20 \mathrm{~h}$ ). After fasting, goats were sacrificed in accordance with Islamic procedures [10,11] followed with skinning and evisceration [11]. Then the carcasses were hung and kept in the $4{ }^{\circ} \mathrm{C}$ chilled room for about $20 \mathrm{~h}$.

\section{Carcass trait observation}

The warm carcass weight was determined and recorded after the skinning and evisceration, while the chilled carcass weight was recorded. After $20 \mathrm{~h}$ of chilling, the length and width of the carcass, including body wall thickness were measured as described by [12]. $\mathrm{The}_{\mathrm{pH}}$ and $\mathrm{pH}_{24}$ of loin muscle (at $12-13^{\text {th }}$ rib) were determined using a Mettler Toledo $\mathrm{pH}$ meter AG CH 8630 with Lot 406-M6DXKS7/25 probe where 2 grams of ground meat were homogenized with deionized water according to Wattanachant [13]. The internal organs, including carcass fat content (heart fat, kidney fat, pelvis fat and visceral fat) were weighed within $1 \mathrm{~h}$ after slaughter.

After chilling, carcasses were cut into half where the right-half carcasses were kept frozen and the left-half parts were dissected for wholesale cuts. Complete International Commission on Illumination [14] color profile of loin muscles and back fat color were determined using a CR-10 Chromometer (Minolta Color Meter, Osaka, Japan). Loin eye area of loin muscle between $12^{\text {th }}$ and $13^{\text {th }}$ ribs was drawn on transparent tracing paper and then was measured using Placom KP90 Digital Planimeter, Japan as described by Ferreira et al. [15]. 
http://wjst.wu.ac.th

Longissimus dorsi muscle was vacuum-packaged and transferred to the Laboratory of Feeds Quality Analysis, Department of Animal Science, Faculty of Natural Resources, and subsequently frozen at -18 ${ }^{\circ} \mathrm{C}$ for proximate analysis.

Table 1 Ingredients and chemical composition of experimental diets.

\begin{tabular}{lcc}
\hline \multicolumn{1}{c}{ Items } & Diets & \multirow{2}{*}{ Crude glycerin supplement } \\
\cline { 2 - 3 } & Control & \\
\hline Ingredients (\%) & 12 & 12 \\
Soybean meal & 26 & 26 \\
Palm kernel cake & 54.3 & 54.3 \\
Ground corn & 0 & 10 \\
Crude glycerin & 1.2 & 1.2 \\
Di-Calcium Phosphate & 2 & 2 \\
Shell flour & 1.5 & 1.5 \\
Salt & 3 & 3 \\
Vegetable oil & 100 & 110 \\
\hline Total & \multicolumn{2}{|c}{} \\
\hline Nutrient composition & 16.43 & 16.44 \\
Crude protein (\%) & 4.56 & 4.77 \\
Gross energy (GE) (Mcal/kg) & 80.24 & 88.00 \\
TDN (\%) & & \\
\hline
\end{tabular}

\section{Meat composition and quality characteristics}

Drip loss, cooking loss and shear force were determined according to the methods of Wattanachant et al. [16] with a slight modification. Samples of drip loss and cooking loss were then used as the shear force samples. The shear force was determined for the raw and cooked muscle samples using a Texture Analyzer (TA-XT plus Stable Micro System Texture Analyzer, UK) equipped with a Warner-Bratzler apparatus at the Research Laboratory Meat Science and Technology, Department of Food Technology, Agro-Industry Faculty, Prince of Songkla University at a speed of $2 \mathrm{~mm} / \mathrm{s}$ and a $50 \mathrm{~kg}$ load cell with 3 replications. The proximate analysis of the meat goat muscle samples was done and measured for moisture, protein, crude fat and ash [17].

Fat distribution in loin muscle (Longissimus dorsi) was determined using CLSM $=$ Confocal Laser Scanning Microscope (Model FV300; Olympus, Tokyo, Japan). Loin samples measuring $2 \times 2 \times 1 \mathrm{~mm}^{3}$ were soaked in Nile Blue A $0.01 \%$ solution for $5-10 \mathrm{~min}$. Then the samples were rinsed with distilled water and put on a microscope slide, covered with a cover slip and observed under CLSM operated in fluorescence mode with $533 \mathrm{~nm}$ excitation wavelength and 400× magnification.

\section{Statistical analysis}

The data were analyzed using Analysis of Variance (ANOVA) while Duncan's New Multiple Range Test was used to compare the significant difference [18]. Moreover, a 2-tailed Pearson Correlation was used to determine the correlation between fat deposition in loin muscle and chemical fat content. All statistical analysis was done using the IBM SPSS Statistics 17.0 computer program. 


\section{Results and discussion}

\section{Carcass trait}

The carcass trait data of this study are presented in Table 2. From the study, no interaction between diet treatment and castration are indicated. When considering the effect of the diet treatment, it was found that goats who received diet with $10 \%$ glycerin had significantly $(\mathrm{P}<0.05)$ higher final weight, slaughter weight, warm and chilled carcass weight than that those fed the control diet. However, $10 \%$ glycerin diet did not statistically differ $(\mathrm{P}>0.05)$ in the chilled carcass and carcass thickness. Moreover, goats on $10 \%$ glycerin diet had lower meat and bone percentages, and lower meat per fat ratio than those on the control diet. The higher fat deposition in the goat carcass and muscle was probably related to the high amount of energy in the experimental diet as described by Mahgoub et al. [19]. In addition, the higher final weight was more likely related to high fat deposition which is concomitant with the biochemical change in the reticulorumen of the goat. Glycerin as a gluconeogenic precursor [20] is converted into propionate in the rumen [9,21] which accelerated the metabolism of pyruvate in the adipose tissue [22] and resulted in a higher deposition of fat in subcutaneous and visceral parts [5].

In terms of castration, castrated male goats illustrated significantly higher $(\mathrm{P}<0.01)$ final weight, slaughter weight, warm and chilled carcass weight, and loin muscle area than the intact male goats. Dressing percentage, carcass length, carcass width and body wall thickness were not affected by castration $(\mathrm{P}>0.05)$. Meat, fat and bone percentage and meat per fat ratio were significantly higher $(\mathrm{P}<$ $0.01)$ in castrated $\mathrm{TN} \times \mathrm{AN}$ goat. The study results were not in accordance with the previous report of the Iranian goat [23] which indicated a non-significant difference by castration in the carcass traits. This was related to the high amount of fat content in parts of the carcass of castrated goats than those of intact males, particularly visceral fat and subcutaneous fat. The lower reproductive tract weight on the castrated goat did not affect carcass measurement, it also indicated that the reproductive tract was not able to produce the male sex hormones which are considered growth promoters and responsible for the distinguishing characteristics of the masculine body [24].

Table 2 Effects of the feeding concentrate containing glycerin and castration on the carcass composition and meat quality of TN $\times$ AN goat $(n=12)$.

\begin{tabular}{lccccccc}
\hline & \multicolumn{2}{c}{ Sex } & \multicolumn{2}{c}{ Diet } & \multicolumn{2}{c}{ P-value } \\
\cline { 2 - 7 } & Intact & Castrated & Control & Supplemented & Sex & Diet & Combination \\
\hline Initial weight, $\mathrm{kg}$ & $26.19 \pm 1.35$ & $25.43 \pm 1.63$ & $25.21 \pm 1.27$ & $24.46 \pm 1.57$ & 0.374 & 0.193 & 0.851 \\
Final weight, kg & $35.26 \pm 1.75$ & $37.91 \pm 1.35$ & $35.51 \pm 1.84$ & $38.14 \pm 1.09$ & 0.004 & 0.003 & 0.050 \\
Slaughter wt., kg & $33.95 \pm 1.92$ & $36.93 \pm 1.13$ & $34.39 \pm 2.07$ & $37.00 \pm 1.16$ & 0.001 & 0.002 & 0.019 \\
Warm carcass wt., kg & $16.45 \pm 0.67$ & $17.44 \pm 0.31$ & $16.20 \pm 0.68$ & $17.94 \pm 0.64$ & 0.039 & 0.001 & 0.252 \\
Chilled carcass wt., kg & $15.88 \pm 1.16$ & $16.78 \pm 0.83$ & $15.64 \pm 0.69$ & $17.26 \pm 0.64$ & 0.061 & 0.001 & 0.169 \\
\% Warm carcass & $48.63 \pm 2.25$ & $47.07 \pm 1.08$ & $47.16 \pm 1.80$ & $48.52 \pm 1.70$ & 0.128 & 0.165 & 0.708 \\
\% Chilled carcass & $46.94 \pm 2.20$ & $45.32 \pm 1.06$ & $45.54 \pm 1.68$ & $46.67 \pm 1.91$ & 0.114 & 0.214 & 0.513 \\
Carcass length, cm & $63.60 \pm 1.64$ & $64.58 \pm 1.88$ & $63.42 \pm 1.77$ & $65.00 \pm 1.46$ & 0.471 & 0.213 & 1.000 \\
Carcass width, cm & $27.10 \pm 0.82$ & $26.75 \pm 1.08$ & $26.75 \pm 1.21$ & $27.10 \pm 0.55$ & 0.615 & 0.615 & 0.456 \\
Carcass thickness, cm & $1.06 \pm 0.19$ & $1.40 \pm 0.30$ & $1.20 \pm 0.26$ & $1.30 \pm 0.37$ & 0.079 & 0.777 & 0.407 \\
Loin area (cm ${ }^{2}$ ) & $10.75 \pm 0.21$ & $12.29 \pm 0.52$ & $11.02 \pm 0.47$ & $11.78 \pm 0.99$ & 0.006 & 0.634 & 0.684 \\
\% Meat & $61.98 \pm 2.88$ & $56.31 \pm 0.36$ & $60.20 \pm 4.23$ & $57.32 \pm 1.55$ & 0.000 & 0.000 & 0.000 \\
\% Fat & $9.95 \pm 2.49$ & $20.37 \pm 1.19$ & $13.80 \pm 6.07$ & $17.84 \pm 4.98$ & 0.000 & 0.000 & 0.050 \\
\% Bone & $22.36 \pm 0.66$ & $18.56 \pm 1.00$ & $20.57 \pm 1.52$ & $19.94 \pm 2.90$ & 0.000 & 0.754 & 0.010 \\
\% Connective tissue & $5.72 \pm 0.30$ & $4.77 \pm 1.02$ & $5.44 \pm 0.78$ & $5.03 \pm 1.03$ & 0.114 & 0.453 & 0.728 \\
Meat / fat ratio & $6.57 \pm 1.73$ & $2.77 \pm 0.17$ & $5.34 \pm 2.68$ & $3.49 \pm 1.23$ & 0.000 & 0.000 & 0.001 \\
Meat /bone ratio & $2.97 \pm 0.69$ & $2.80 \pm 0.41$ & $2.98 \pm 0.59$ & $2.76 \pm 0.49$ & 0.792 & 0.333 & 0.054 \\
\hline
\end{tabular}




\section{Carcass pH}

The castration treatment caused a significant effect $(\mathrm{P}<0.01)$ on $\mathrm{pH}_{0}$ of $\mathrm{TN} \times \mathrm{AN}$ Longissimus dorsi muscle. $\mathrm{pH}_{24}$ was significantly affected $(\mathrm{P}<0.01)$ by the glycerin and castration (Table 3$) \cdot \mathrm{pH}_{24}$ in the study was higher than the normal ultimate $\mathrm{pH}(5.6-5.8)$ [25]. The elevation in loin muscle $\mathrm{pH}_{24} \mathrm{was}$ similarly reported for the Nellore bull loin muscle $\mathrm{pH}$ [26]. Crude glycerin inclusion in the Nellore bulls diet generated a high $\mathrm{pH}_{\mathrm{u}}$ (ultimate $\mathrm{pH}$ ). Muscle with a high $\mathrm{pH}_{\mathrm{u}}$ tends to have no residual glycogen [27] or because the glycolytic enzymes are inactive due to acidic conditions [28]. The glycogen level can accelerate glycolysis in muscle which is predicted as the starting point to change the ultimate $\mathrm{pH}$. The ultimate $\mathrm{pH}$ would get higher as the glycogen level in the muscle decreased [27]. Differences in species, type of muscle, variability of animals, pre-slaughter circumstances and environmental temperature could lead to differences in the $\mathrm{pH}$ value [27].

\section{Color}

Color is a prime criteria influencing purchase decisions of the consumers [29]. In this study, glycerin supplementation had a significant effect $(\mathrm{P}<0.05)$ on the redness $\left(a^{*}\right)$ of Longissimus dorsi muscle color, but no significant difference in lightness and yellowness values was indicated (Table 3). In contrast with glycerin supplementation, the castrated group had higher $(\mathrm{P}<0.05)$ color value in lightness, redness and yellowness compared with the intact group. The difference in the meat color score, especially in lightness $\left(L^{*}\right)$ could be possibly affected by the high fat deposition in the muscle. This was in agreement with Fiems and Boucque [30] who found high correlation between fat deposition in the muscle of the bull and the lightness.

Table 3 Effect of glycerin supplementation and castration on the physical properties and proximate composition of Longissimus dorsi muscle of TN $\times$ AN goat $(\mathrm{n}=12)$.

\begin{tabular}{|c|c|c|c|c|c|c|c|}
\hline & \multicolumn{2}{|c|}{ Sex } & \multicolumn{2}{|c|}{ Diet } & \multicolumn{3}{|c|}{ P-value } \\
\hline & Intact & Castrated & Control & Supplemented & Sex & Diet & Combination \\
\hline \multicolumn{8}{|c|}{ Physical characteristics } \\
\hline $\mathrm{pH}_{0}$ & $6.52 \pm 0.16$ & $6.06 \pm 0.23$ & $6.20 \pm 0.30$ & $6.20 \pm 0.31$ & 0.000 & 0.426 & 0.446 \\
\hline $\mathrm{pH}_{24}$ & $6.19 \pm 0.22$ & $5.71 \pm 0.05$ & $5.83 \pm 0.17$ & $6.05 \pm 0.37$ & 0.000 & 0.000 & 0.000 \\
\hline \multicolumn{8}{|l|}{ Muscle color } \\
\hline$L^{*}$ & $28.55 \pm 0.55$ & $30.20 \pm 0.33$ & $29.29 \pm 1.07$ & $29.77 \pm 0.76$ & 0.000 & 0.277 & 0.903 \\
\hline$a^{*}$ & $11.15 \pm 1.12$ & $13.17 \pm 1.01$ & $11.65 \pm 1.15$ & $13.38 \pm 1.18$ & 0.000 & 0.000 & 0.893 \\
\hline$b^{*}$ & $2.88 \pm 0.36$ & $3.63 \pm 0.39$ & $2.98 \pm 0.47$ & $3.38 \pm 0.54$ & 0.015 & 0.124 & 0.855 \\
\hline Drip loss, $\%$ & $1.38 \pm 0.09$ & $1.31 \pm 0.20$ & $1.35 \pm 0.10$ & $1.33 \pm 0.20$ & 0.477 & 0.756 & 0.993 \\
\hline Cooking loss, $\%$ & $20.45 \pm 2.22$ & $20.83 \pm 1.92$ & $22.12 \pm 0.52$ & $18.42 \pm 0.46$ & 0.213 & 0.000 & 0.406 \\
\hline \multicolumn{8}{|l|}{ Shear force, $\mathrm{kg}$} \\
\hline Raw & $5.84 \pm 0.50$ & $5.60 \pm 0.35$ & $5.77 \pm 0.44$ & $5.62 \pm 0.44$ & 0.359 & 0.745 & 0.990 \\
\hline Cooked & $5.84 \pm 0.45$ & $5.47 \pm 0.40$ & $5.73 \pm 0.43$ & $5.59 \pm 0.50$ & 0.040 & 0.277 & 0.883 \\
\hline \multicolumn{8}{|c|}{ Proximate composition, $\%$} \\
\hline Moisture & $74.04 \pm 0.52$ & $73.46 \pm 0.24$ & $73.65 \pm 0.54$ & $73.94 \pm 0.36$ & 0.078 & 0.525 & 0.810 \\
\hline Protein & $23.44 \pm 0.46$ & $23.44 \pm 0.38$ & $23.59 \pm 0.40$ & $23.25 \pm 0.36$ & 0.778 & 0.163 & 0.246 \\
\hline Crude fat & $2.45 \pm 1.31$ & $5.91 \pm 1.28$ & $3.20 \pm 2.17$ & $5.46 \pm 1.71$ & 0.001 & 0.014 & 0.534 \\
\hline Ash & $1.07 \pm 0.09$ & $1.05 \pm 0.06$ & $1.08 \pm 0.09$ & $1.04 \pm 0.04$ & 0.543 & 0.310 & 0.720 \\
\hline
\end{tabular}


http://wjst.wu.ac.th

In the diet treatment, goats fed with glycerin had a higher $\mathrm{pH}_{24}$ compared with goats fed without glycerin, while the castrated goat generated lower $\mathrm{pH}_{24}$ compared with the intact goat. High $\mathrm{pH}_{24}$ increased the water retention of the muscle protein and lead to less light reflection from the available free water [31].

Meat color is affected by endogenous and exogenous factors [32]. The endogenous factors are $\mathrm{pH}$, muscle sources, lipid oxidation and mitochondrial activity, while exogenous factors are ligands, antioxidant, and pro-oxidants presence. Age could change the color of the meat as muscle pigment concentration increases [33]. Apart from that, long exposure of oxygen might also lead to discoloration of the meat, known as metmyoglobin [34].

\section{Physiochemical of loin muscle}

\section{Drip and cooking loss}

The drip loss of Longissimus dorsi muscle was not affected $(\mathrm{P}>0.05)$ by the dietary treatment and castration, however cooking loss was significantly affected $(\mathrm{P}<0.05)$ by the glycerin diet. Castration showed a non-significant difference $(\mathrm{P}>0.05)$ in both drip loss and cooking loss of the muscle but the glycerin treatment statistically differed $(\mathrm{P}<0.05)$ in cooking loss of the muscle. Muscle from the goats fed with glycerin yielded significantly lower cooking loss compared with group fed without glycerin. The results confirmed that glycerin could reduce free water in the muscle which lead to muscle water retention [35].

\section{Shear force}

Longissimus dorsi raw muscle shear force showed no significant difference $(\mathrm{P}>0.05)$ caused by the treatments (Table 3). The castration treatment could lower $(\mathrm{P}<0.05)$ the shear force of cooked Longissimus dorsi muscle. A shear force of $5.5 \mathrm{~kg}$ is the limit of consumer acceptance and if exceeded it might reduce consumer acceptance [2]. Nevertheless, muscle from castrated goats had a lower shear force than muscles from the intact goats. Thus, meat from castrated goats tends to be more tender than the intact which is concomitant with the amount of muscle fat. Castration has been reported as farm management practice which could improve the fat content, reducing muscle collagen deposition and increasing muscle fat [36]. In addition, muscle fat may loosen up the micro structure of the meat which causes meat to be tender [37].

\section{Proximate composition}

Proximate composition of the Longissimus dorsi is shown in Table 3. The moisture, protein and ash content of Longissimus dorsi muscles showed no marked difference in both castration and dietary treatments. The result coincided with previous reports [20] in which glycerin in the goat diet had no significant effect on muscle chemical composition. However, glycerin significantly affected $(\mathrm{P}<0.05)$ the amount of crude fat of $m$. longissimus dorsi. Supplementing crude glycerin in a ruminant animal may cause elevation of propionate, increase in butyric acid, decrease in acetate production and also an increase in propionate:acetate ratio in ruminal fluid. Propionate is a major precursor of glucose synthesis in ruminants [22]. Propionate is known as an accelerator of metabolism of pyruvate in adipose tissue and also accelerates gluconeogenesis from lactate (by the kidney) and pyruvate (by the lactating cow) [22].

Despite the crude glycerin effect, the crude fat amount was significantly different $(\mathrm{P}<0.05)$ from the castration treatment. The castrated group gained higher muscle fat content compared with the intact group (Table 3). Many researchers [23,38] have reported that castrated animals gained higher fat content, especially intramuscular fat and subcutaneous fat than intact animals. A reduction in the production of testosterone, which can be evidenced from reduction in weight of testes in castrated goats (data not shown), makes the castrated goat have reduced physical activities [38] which led to increased deposits of glucose which is then converted into fat.

The crude fat amount of Longissimus dorsi muscle was correlated with the amount of carcass fat. The correlation between carcass fat and muscle fat is shown in Table 4. A positive correlation was observed between the carcass fat and muscle fat of the $\mathrm{TN} \times \mathrm{AN}$ goat. The muscle fat increased as the 
http://wjst.wu.ac.th

carcass fat increases. The significant level of both fat content correlation was $0.005(\mathrm{P}=0.005)$ and the correlation score was 0.807 close to +1 which means a positive correlation between the 2 fat contents.

Table 4 Correlation between carcass fat and Longissimus dorsi muscle fat of TN $\times$ AN goat treated with glycerin and castration.

\begin{tabular}{llcc}
\hline & & ${ }^{1}$ Carcass fat & ${ }^{\mathbf{1}}$ Muscle fat \\
\hline & Pearson Correlation & 1 & $0.807^{* *}$ \\
${ }^{1}$ Carcass fat & Sig. (2-tailed) & & 0.005 \\
& N & 12 & 12 \\
& Pearson Correlation & $0.807^{* *}$ & 1 \\
${ }^{1}$ Muscle fat & Sig. (2-tailed) & 0.005 & 12 \\
& N & 12 & 12 \\
\hline
\end{tabular}

${ }^{1}$ Carcass fat, total fat in carcass (visceral fat, kidney fat, pelvic fat, heart fat, subcutaneous fat and intermuscular fat).

${ }^{1}$ Muscle fat, crude fat contained in Longissimus dorsi muscle.

**Correlation was significant at the 0.01 level (2-tailed).

While determining the crude fat content of Longissimus dorsi muscle, loin muscle fat distribution was also observed by visual micro structure and is depicted in Figure 1. The loin muscle fat distribution increased in every treatment combination group. The effect of the glycerin diet could be visually seen using CLSM. Supplementing crude glycerin in the goat concentrate diet, might increase the fat content of the muscle since crude glycerin would be fermented as propionate which is the main carbon source for fat tissue deposition [20].

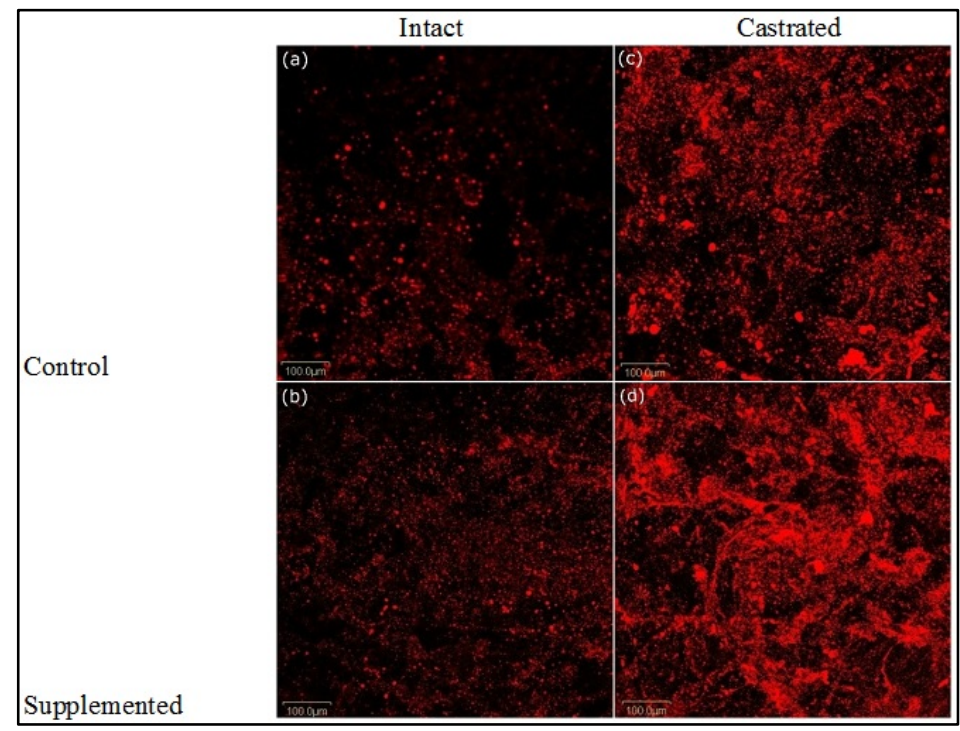

Figure 1 Confocal Laser Scanning Microscope result of Longissimus dorsi muscle of TN $\times$ AN goat treated with castration and glycerin supplementation. (a) control group, (b) intact group fed with glycerin, (c) castrated group fed with control diet and (d) castrated group fed with glycerin. 
http://wjst.wu.ac.th

The castration treatment group showed a marked difference in fat distribution (Figure 1). Fat distribution was higher in the muscle of castrated goats than of the intact goats. The high amount of loin muscle fat content is most likely due to the castration. Castration, which is suggested to be done at an early age, could improve the marbling degree of carcass quality and may affect the consumer acceptance value $[38,39]$. The longer the testosterone deficiency period the higher the fat deposition [40].

\section{Conclusions}

It could be concluded that feeding a concentrate diet with $10 \%$ glycerin and castration could lead to better slaughter weight, warm carcass percentage, of the $\mathrm{TN} \times \mathrm{AN}$ goats than those fed a diet without glycerin. A feeding diet with $10 \%$ glycerin and castration resulted in high fat deposition in the carcass and muscle leading to a lower shear force value in the muscle.

\section{Acknowledgements}

The authors would like to thank the Thailand's Education Hub for Southern Region of ASEAN Countries (TEH-AC of year 2014) scholarship. We also would like to thank Dr. Aronal A. Putra and other colleagues for valuable help. Thank also addressed to The Small Ruminant Research and Development Center (SRRDC), and Animal Nutrition Laboratory, Department of Animal Science Faculty of Natural Resources, and Meat Science and Technology Research Laboratory, Faculty of Agro-Industry, Prince of Songkla University for the support.

\section{References}

[1] FAO. FAOSTAT for 2014, Available at: http://faostat3.fao.org/download/Q/QA/E, accessed July 2016.

[2] NH Casey. Goat meat in human nutrition. In: Proceedings of the $5^{\text {th }}$ International Conference on Goats. New Delhi, India, 1992, p. 581-98.

[3] MT Diaz, S Velasco, V Caneque, S Lauzurica, FRD Huidobro, C Perez, J Gonzales and C Manzanares. Use of concentrate or pasture for fattening lambs and its effect on carcass and meat quality. Small Rumin. Res. 2002; 43, 257-68.

[4] AY Abdullah and HS Musallam. Effect of different levels of energy on carcass composition and meat quality of male black goats kids. Livest. Sci. 2007; 107, 70-80.

[5] S Silva, A Teixeira and M Font-i-Furnols. Intramuscular Fat and Marbling. In: M Font-i-Furnols, M Čandek-Potokar, MP Povše and C Maltin (eds.) Handbook Reference Methods Meat Quality Assessment. COST, EU, 2015, p. 33-44.

[6] DE Mushi, J Safari, LA Mtenga, GC Kifaro and LO Eik. Effects of concentrate levels on fattening performance, carcass and meat quality attributes of Small East African Norwegian crossbred goats fed low quality grass hay. Livest. Sci. 2009; 124, 148-55.

[7] Department of Alternative Energy Development and Efficiency. Biofuel Status and Policy, Available at: https://www.mtec.or.th/files/chanpen/1_DEDE.pdf, accessed November 2016.

[8] JC Thompson and BB He. Characterization of crude glycerol from biodiesel production from multiple feedstocks. Appl. Eng. Agric. 2006; 22, 261-5.

[9] P Chanjula, P Pakdeechanuan and S Wattanasit. Effects of feeding crude glycerin on feedlot performance and carcass characteristics in finishing goats. Small Rumin. Res. 2015; 123, 95-102.

[10] TAS. Halal Food. TAS 8400-2007. National Bureau of Agricultural Commodity and Food Standard, Ministry of Agriculture and Cooperatives, Thailand, 2007.

[11] TAS. Good Manufacturing Practices for Goat and Sheep Abattoir. TAS 9040-2013. National Bureau of Agricultural Commodity and Food Standard, Ministry of Agriculture and Cooperatives, Thailand, 2013.

[12] CAT Marques, AN de Medeiros, RG Costa, FFR de Carvalho, MJ de Araújo and JNC Torreão. Performance and carcass traits of Moxotó growing goats supplemented on native pasture under semiarid conditions. Rev. Bras. Zootec. 2014; 43, 151-9. 
http://wjst.wu.ac.th

[13] S Wattanachant. 2004, Chemical Compositions, Properties and Structure of Muscle Affecting Textural Characteristics of Meat from Thai Indigenous Chicken and Broiler. Ph. D. Thesis. Prince of Songkla University, Songkhla, Thailand.

[14] CIE. Recommendations on Uniform Color Spaces-color Difference Equations, Psychomettic Color Terms. Commision Int Eclairage, Paris, 1978.

[15] OGL Ferreira, FD Rossi, RAT Coelho, VF Fucilini and M Benedetti. Measurement of rib-eye area by the method of digital images. Rev. Bras. Zootec. 2012; 41, 811-4.

[16] S Wattanachant, S Benjakul and DA Ledward. Composition, color, and texture of Thai indigenous and broiler chicken muscles. Poult. Sci. 2004; 83, 123-8.

[17] AOAC. Official Method of Analysis. 17 $7^{\text {th }}$ Eds. Association of Official Analytical Chemists, Maryland, 2000.

[18] M Kaps and W Lamberson. Biostatistics for Animal Science. CABI, Cambridge, USA, 2004.

[19] O Mahgoub, CD Lu, MS Hameed, A Richie, AS Al-Halhali and K Annamalai. Performance of Omani goats fed diets containing various metabolizable energy densities. Small Rumin. Res. 2005; 58, 175-80.

[20] KS da Rocha, HN Parente, PMO Maia, FE Maia, AJ dos Santos, QRCR do Egypto, MM Suely and BAS Malveira. Fatty acid profile, chemical composition, and sensory effects of crude glycerin on the longissimus dorsi of crossbred Boer goat kids. Rev. Bras. Zootec. 2015; 44, 263-8.

[21] JC Dias, ALF da Silveira, JAC Lançanova, JAG Hill and JL Moletta. Crude glycerin in meat goat diets: intake, performance and carcass traits. Ciênc Rural 2016; 46, 719-24.

[22] L Reshef, J Niv and B Shapiro. Effect of propionate on lipogenesis in adipose tissue. J. Lipid Res. $1967 ; 8,682-7$.

[23] MJ Zamiri, B Eilami and MR Kianzad. Effects of castration and fattening period on growth performance and carcass characteristics in Iranian goats. Small Rumin. Res. 2012; 104, 55-61.

[24] MO Mudalal, I Bushara, DM Mekki and SA Babiker. Effect of nutrition and castration on carcass measurements, wholesale cuts and carcass composition of male Desert Goats. Glob. J. Anim. Sci. Res. 2014; 2, 97-101.

[25] RA Hunter. High-molasses diets for intensive feeding of cattle. Anim. Prod. Sci. 2012; 52, 787-94.

[26] MC Françozo, IN Prado, U Cecato, MV Valero, F Zawadzki, OL Ribeiro, RM Prado and JV Visentainer. Growth performance, carcass characteristics and meat quality of finishing bulls fed crude glycerin-supplemented diets. Braz. Arch. Biol. Tech. 2013; 56, 327-36.

[27] RA Lawrie and D Ledward. Lawrie's Meat Science. Woodhead Publishing, England, 2014.

[28] JD Merthayasa, IK Suada and KK Agustina. Water holding capacity, pH, color, odor and texture of Bali Beef and Wagyu Beef. Indonesia Med. Veterinus 2015; 4, 16-24.

[29] RA Mancini and MC Hunt. Current research in meat color. Meat Sci. 2005; 71, 100-21.

[30] LO Fiems and CV Boucque. Relationship between fat depots in carcasses of beef bulls and tenderness. Meat Sci. 2000; 56, 41-7.

[31] JF Lage, TT Berchielli, ES Vito, RA Silva, AF Ribeiro, RA Reis, EE Dallantonia, LR Simonetti, LM Delevatti and M Machado. Fatty acid profile, carcass and meat quality traits of young Nellore bulls fed crude glycerin replacing energy sources in the concentrate. Meat Sci. 2014; 96, 1158-64.

[32] H Toplu, D Oral, EO Goksoy and A Nazligul. Effects of slaughter age and gender on carcass characteristics of Turkish indigenous Hair goat kids reared under an extensive production system. Arch. Tierz. 2013; 56, 75-88.

[33] E Huff-Lonergan and SM Lonergan. Mechanisms of water-holding capacity of meat: The role of postmortem biochemical and structural changes. Meat Sci. 2005; 71, 194-204.

[34] AM Pearson. Quality Attributes and Their Measurement in Meat, Poultry and Fish Products. Vol. IX. Springer, US, 2013.

[35] CE Eiras, JA Marques, RM do Prado, MV Valero, EG Bonafé, F Zawadzki, D Perotto and IN do Prado. Glycerine levels in the diets of crossbred bulls finished in feedlot: Carcass characteristics and meat quality. Meat Sci. 2014; 96, 930-6.

[36] S Segato, C Elia, C Mazzini, C Bianchi and I Andrighetto. Effect of castration age on carcass traits and meat quality of Simmental bulls. Ital. J. Anim. Sci. 2005; 4, 263-5. 
http://wjst.wu.ac.th

[37] MJA den Hertog-Meischke, RJLM van Laack and FJM Smulders. The water-holding capacity of fresh meat. Vet. Quart. 1997; 19, 175-81.

[38] SG Haddad, MQ Husein and RW Sweidan. Effects of castration on growth performance and carcass characteristics of Awassi lambs fed high concentrate diet. Small Rumin. Res. 2006; 65, 149-53.

[39] T Kebede, T Lemma, H Dinka, M Guru and A Sisay. Growth performance and carcass characteristics of Arsi-Bale goats castrated at different ages. World Appl. Sci. J. 2008; 4, 545-53.

[40] J Sales. Quantification of the effects of castration on carcass and meat quality of sheep by metaanalysis. Meat Sci. 2014; 98, 858-68. 